SYSTEMATIC REVIEW

\title{
Donor human milk versus formula for preventing necrotising enterocolitis in preterm infants: systematic review
}

\author{
W McGuire, M Y Anthony
}

See end of article for authors' affiliations

.....................

Correspondence to: Dr McGuire, Tayside Institute of Child Health

Ninewells Hospital and Medical School, Dundee DDI 9SY, Scotland, UK: w.mcguire@dundee.ac.uk

Accepted 23 May 2002

\begin{abstract}
Objectives: To determine if enteral feeding with donor human milk compared with formula milk reduces the incidence of necrotising enterocolitis (NEC) in preterm or low birthweight infants. Methods: Systematic review and meta-analysis of randomised controlled trials.

Results: Four small trials, all initiated more than 20 years ago, fulfilled the prespecified inclusion criteria. None of the trials individually found any statistically significant difference in the incidence of NEC. However, meta-analysis found that feeding with donor human milk was associated with a significantly reduced relative risk (RR) of NEC. Infants who received donor human milk were three times less likely to develop NEC (RR 0.34; 95\% confidence interval (CI) 0.12 to 0.99), and four times less likely to have confirmed NEC (RR $0.25 ; 95 \% \mathrm{Cl} 0.06$ to 0.98 ) than infants who received formula milk.

Conclusions: It may be appropriate to consider further larger trials to compare growth, development, and the incidence of adverse outcomes, including NEC, in preterm infants who receive donor human milk versus formula milk.
\end{abstract}

$\mathrm{H}$ uman breast milk is the recommended source of enteral nutrition for preterm infants. ${ }^{1}$ A putative benefit is that the delivery of immunoprotective factors to the immature gut mucosa may decrease the risk of necrotising enterocolitis (NEC). Case-control data indicate that NEC is less common in infants nourished with human milk than in those fed with formula milk. ${ }^{2}$ Large prospective studies have found a lower incidence of NEC in preterm infants fed with their own mother's expressed breast milk compared with those fed with formula milk. ${ }^{3}$ However, the outcomes in these nonrandomised trials may have been affected by known and unknown confounding variables related to maternal preference for feeding with human milk. A recent Cochrane systematic review did not find any randomised controlled trials that compared feeding of preterm infants with their own mother's expressed breast milk versus formula milk. ${ }^{5}$ This may be due to a perceived difficulty of allocating an alternative enteral feed to infants whose mothers wish to feed with expressed breast milk.

When the expressed breast milk of the preterm infant's mother is not available, an alternative is banked milk from donor mothers. However, donor human milk, typically the breast milk of mothers who have delivered at term, has a lower content of protein and host defence protein than the breast milk of a mother who has delivered a preterm infant..$^{6-8}$ Feeding with unfortified donor human milk, especially when compared with nutrient supplemented formula milk, is associated with lower rates of growth in preterm infants, at least in the short term. ${ }^{9}$ However, it is unclear whether the non-nutrient components of donor human milk may confer immunoprotective benefits. The aim of this systematic review is to examine the evidence that enteral feeding with donor human milk versus formula milk reduces the risk of development of NEC in preterm infants.

\section{METHODS}

\section{Prespecified inclusion criteria}

Randomised and quasi-randomised controlled trials comparing enteral feeding with donor human milk versus formula milk in preterm $(<37$ weeks gestation) or low birthweight $(<2.5 \mathrm{~kg})$ infants were included. The allocated milk feed should have formed the entire enteral intake, not a supplement to the expressed breast milk of the mother. Trials in which parenteral nutritional support is available during the period of advancement of enteral feeds were acceptable, provided that the groups received similar treatment other than the type of milk feed. The following outcomes were considered:

- NEC, as defined and reported by individual trials;

- confirmed NEC, radiological confirmation showing gas in the portal venous system or free air in the abdomen, or when NEC is confirmed at surgery or autopsy.

\section{Search strategy for identification of studies}

The standard search strategy of the Cochrane Neonatal Review Group was used. This included electronic searches of the Cochrane Controlled Trials Register (CCTR; 2001, Issue 2), Medline (1966 to October 2001), and Embase (1980 to October 2001). No language restriction was applied. References in studies identified as relevant, and in previous reviews and standard textbooks of neonatal medicine and nutrition were examined.

The search strategy involved the following keywords, using the search fields of abstract, MeSH subject heading, exploded subject heading, publication type, registry number word, subject heading word, text word, and title: (1) "Infant-Newborn"/ all subheadings; (2) infan*; (3) neonat*; (4) newborn; (5) prematur*; (6) preemie; (7) low birth weight; (8) (small or light) near3 (date* or gestational age); (9) LBW; (10) VLBW; (11) SGA; (12) growth restrict*; (13) growth retard*; (14) IUGR; (15) explode "Infant-Nutrition"/ all subheadings; (16) explode "Feeding-Methods"/ all subheadings; (17) milk; (18) breast near3 feed*; (19) breast near3 fed; (20) formula, (21) $(\mathrm{PT}=$ "CLINICAL-TRIAL").

Abbreviations: NEC, necrotising enterocolitis; RR, relative risk; $\mathrm{Cl}$, confidence interval; RD, risk difference 
Table 1 Characteristics of included studies: methods

\begin{tabular}{llllll}
\hline Trial (year published) & $\begin{array}{l}\text { Method of } \\
\text { randomisation }\end{array}$ & $\begin{array}{l}\text { Allocation } \\
\text { concealment }\end{array}$ & $\begin{array}{l}\text { Blinding of } \\
\text { intervention }\end{array}$ & $\begin{array}{l}\text { Complete } \\
\text { follow up }\end{array}$ & $\begin{array}{l}\text { Blinding of } \\
\text { outcome } \\
\text { measurement }\end{array}$ \\
\hline Gross $(1983)^{12}$ & Random number table & Yes & No & Yes & Can't tell \\
Lucas $(1990)^{3}$ & Sealed envelopes & Yes & No & Yes & Can't tell \\
Svenningsen $(1982)^{10}$ & Not stated & Can't tell & No & Yes & Can't tell \\
Tyson $(1983)^{11}$ & Sealed envelopes & Yes & No & Yes & Can't tell \\
\hline
\end{tabular}

The title and abstract of studies identified by the above search strategy were screened by the first reviewer. The full text of the report of each study identified as of potential relevance was rescreened by both reviewers. The decision to include or exclude a specific study was made by consensus of the two reviewers.

The criteria and standard methods of the Cochrane Neonatal Review Group were used to assess the methodological quality of the included trials. Quality of the trials was evaluated in terms of allocation concealment, blinding of parents or carers and assessors to intervention, and completeness of assessment in all randomised subjects. Additional information was requested from the authors of each trial to clarify methodology and results as necessary.

A data collection form was used to aid extraction of relevant information and data from each included study. Each reviewer extracted the data separately, compared data, and resolved differences by consensus. Effects were expressed as relative risk (RR) and 95\% confidence interval (CI) and risk difference (RD) and 95\% CI for a categorical data, fixed effect model for meta-analysis.

\section{RESULTS}

\section{Description of studies}

Eleven trials that appeared to be relevant were identified in the first round of screening. Four of these trials fulfilled the inclusion criteria and contributed to the meta-analysis. ${ }^{3}{ }^{10-12}$ Table 1 gives details of the methods and quality assessment, and table 2 gives details of participant characteristics, interventions, and outcomes. Seven of the trials were excluded in the second round of screening, with complete agreement between the reviewers. ${ }^{13-20}$ Five of these trials (six reports) randomised preterm infants to feeding with donor human milk versus formula, but did not report NEC as an outcome. ${ }^{13-18}$ Two trials were non-randomised, although this was not clear from the title and abstract. ${ }^{19} 20$

\section{Necrotising enterocolitis}

None of the four included trials showed any statistically significant difference in the incidence of NEC. When the data from the trials were combined in a meta-analysis, we found a borderline statistically significant difference in the incidence of NEC: RR 0.34 (95\% CI 0.12 to 0.99 ); RD -0.05 (95\% CI -0.1 to 0.00 ) (fig l).

\section{Confirmed necrotising enterocolitis}

None of the four included trials showed a statistically significant difference in the incidence of confirmed NEC. In a combined meta-analysis we found a borderline statistically significant difference in the incidence of confirmed NEC: RR 0.25 (95\% CI 0.06 to 0.98 ); RD -0.04 (95\% CI -0.09 to 0.00 ) (fig 2).

In a post hoc analysis, we included the data from a trial ${ }^{3}$ in which infants received donor human milk or formula as a supplement to the expressed breast milk of the infant's mother. The investigators did not find any significant difference in the incidence of NEC. When the data were combined with those of the previously included trials, the

Table 2 Characteristics of included studies: participants, intervention, and outcome

\begin{tabular}{|c|c|c|c|c|c|}
\hline $\begin{array}{l}\text { Trial (year } \\
\text { published) }\end{array}$ & Participants & Setting & Interventions & Outcomes $(n / N)$ & Notes \\
\hline Gross $(1983)^{12}$ & $\begin{array}{l}67 \text { preterm infants } \\
\text { ( } 27-33 \text { weeks gestation). } \\
\text { Birth weight < } 1600 \mathrm{~g} \text {. } \\
\text { Excluded if "congenital } \\
\text { anomaly or major } \\
\text { disease, or if growth } \\
\text { restricted." }\end{array}$ & $\begin{array}{l}\text { Department of Pediatrics, } \\
\text { Duke University, USA. } \\
\text { 1980-82. }\end{array}$ & $\begin{array}{l}\text { Donor human, term } \\
(\mathrm{N}=20) \text { or preterm } \\
(\mathrm{N}=21) \text { milk versus } \\
\text { standard-calorie formula } \\
\text { milk }(\mathrm{N}=26) . \text { Feeds } \\
\text { assigned until infant } \\
\text { weight reached } 1800 \mathrm{~g}\end{array}$ & $\begin{array}{l}\text { NEC (confirmed): } \\
\text { Donor human milk: } 1 / 41 \\
\text { Formula milk: } 6 / 26\end{array}$ & $\begin{array}{l}\text { NEC was a withdrawal } \\
\text { criterion not primary } \\
\text { end-point of the study. }\end{array}$ \\
\hline Lucas $(1990)^{3}$ & $\begin{array}{l}159 \text { infants, birth weight } \\
<1850 \mathrm{~g} \text {. Infants with } \\
\text { congenital abnormalities } \\
\text { excluded. }\end{array}$ & $\begin{array}{l}\text { Neonatal units in Anglia, } \\
\text { UK. } \\
\text { Early 1980s }\end{array}$ & $\begin{array}{l}\text { Donor (mainly drip) } \\
\text { human milk ( } \mathrm{N}=83 \text { ) } \\
\text { versus calorie-enriched } \\
\text { formula as sole diet } \\
(\mathrm{N}=76)\end{array}$ & $\begin{array}{l}\text { NEC (suspected and } \\
\text { confirmed): } \\
\text { Donor human milk: } 3 / 83 \\
\text { Formula milk: } 6 / 76 \\
\text { NEC (confirmed only): } \\
\text { Donor human milk: 1/83 } \\
\text { Formula milk: } 4 / 76\end{array}$ & $\begin{array}{l}\text { Parallel study assessed } \\
\text { outcomes in infants who } \\
\text { received donor human milk } \\
\text { or formula as a supplement } \\
\text { to the mother's expressed } \\
\text { breast milk. }\end{array}$ \\
\hline $\begin{array}{l}\text { Svenningsen } \\
(1982)^{10}\end{array}$ & $\begin{array}{l}36 \text { low birth weight } \\
\text { infants. }\end{array}$ & $\begin{array}{l}\text { Department of } \\
\text { Paediatrics, University } \\
\text { Hospital, Lund, Sweden. } \\
\text { Early 1980s }\end{array}$ & $\begin{array}{l}\text { Donor human milk }(\mathrm{N}=6) \\
\text { versus standard-calorie } \\
\text { formula milk }(\mathrm{N}=30)\end{array}$ & $\begin{array}{l}\text { NEC (confirmed): } \\
\text { Donor human milk: } 0 / 6 \\
\text { Formula milk: } 0 / 30\end{array}$ & $\begin{array}{l}\text { Feeds randomly allocated } \\
\text { in second week of life. }\end{array}$ \\
\hline Tyson (1983) & $\begin{array}{l}81 \text { very low birth weight } \\
\text { infants, excluding infants } \\
\text { with "any significant } \\
\text { illness" or those who } \\
\text { required ventilatory } \\
\text { support at day } 10 \text { of life }\end{array}$ & $\begin{array}{l}\text { Department of Pediatrics, } \\
\text { University of Texas, } \\
\text { Dallas, USA. } \\
\text { Early 1980s }\end{array}$ & $\begin{array}{l}\text { Donor human milk } \\
(\mathrm{N}=37) \text { versus } \\
\text { calorie-enriched formula } \\
(\mathrm{N}=44) \text {. }\end{array}$ & $\begin{array}{l}\text { NEC (suspected and } \\
\text { confirmed): } \\
\text { Donor human milk: } 0 / 37 \\
\text { Formula milk: } 2 / 44 \\
\text { NEC (confirmed only): } \\
\text { Donor human milk: } 0 / 37 \\
\text { Formula milk: } 1 / 44\end{array}$ & $\begin{array}{l}\text { NEC reported as } \\
\text { withdrawal criterion rather } \\
\text { than outcome. Feeds } \\
\text { allocated on the tenth day } \\
\text { of life and continued until } \\
\text { the infant reached a weight } \\
\text { of } 2000 \mathrm{~g}\end{array}$ \\
\hline
\end{tabular}




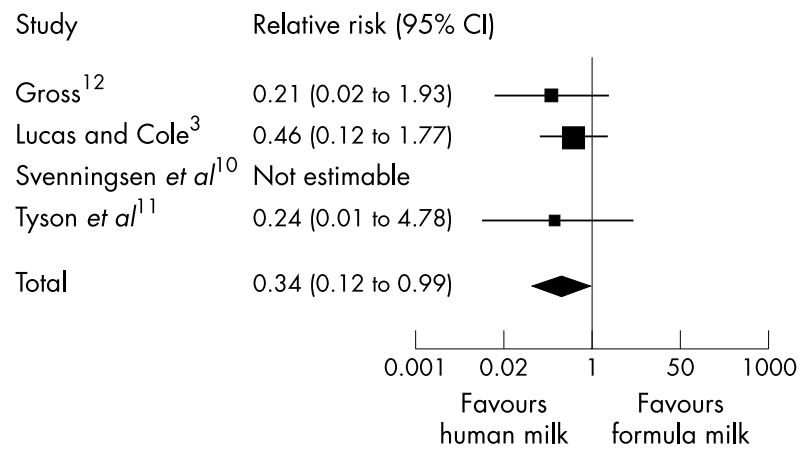

Figure 1 Relative risk of necrotising enterocolitis in infants randomised to donor human milk versus formula milk.

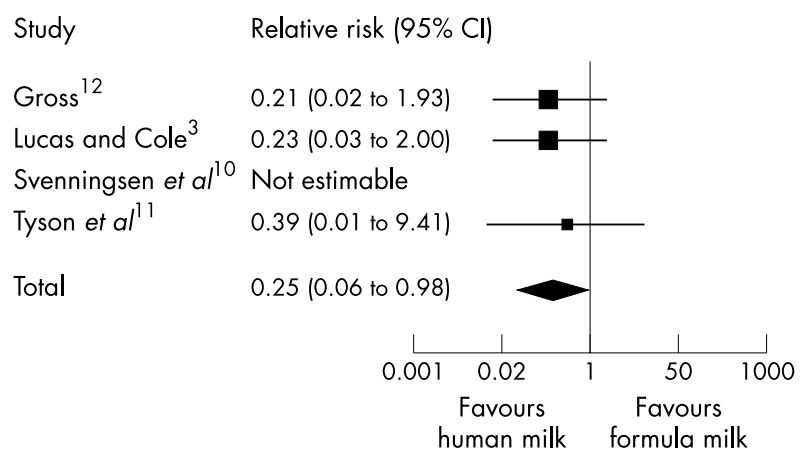

Figure 2 Relative risk of confirmed necrotising enterocolitis in infants randomised to donor human milk versus formula milk.

meta-analysis did not find any significant difference in the incidence of NEC: RR 0.68 (95\% CI 0.34 to 1.37); RD -0.02 ( $95 \%$ CI -0.05 to 0.01 ). However, we found a borderline significant difference in the incidence of confirmed NEC: RR 0.30 ( $95 \%$ CI 0.11 to 0.87 ); RD -0.03 (95\% CI -0.06 to 0.00 ).

\section{DISCUSSION}

The data available from the included trials suggest that feeding with donor human milk rather than formula milk may reduce the incidence of NEC in preterm or low birthweight infants. NEC is three times less likely, and confirmed NEC is four times less likely, in infants who were randomised to receive donor human milk rather than formula milk. Although the relative risk estimates were statistically significant, the risk difference estimates were not, and the overall effect is described as of borderline statistical significance. Consequently, the estimated number needed to treat (one case of confirmed NEC averted if 20 infants receive donor human milk) should be applied with caution. Moreover, in the included trials, parents or carers were not blind to the intervention, and the possibility that these are biased outcomes remains.

Are these findings of clinical significance? All of the included studies were initiated over 20 years ago. Since then, in addition to changes in the availability of formula milk adapted for preterm infants, and nutrient fortifiers for human milk, there have been changes to other aspects of the antenatal and subsequent management of preterm infants. These changes, including the use of antenatal steroids and exogenous surfactant, may have altered the potential impact of feeding with donor human milk on the risk of NEC. It may be that the findings of this review are not wholly applicable to the modern population of preterm and low birthweight infants. Additional caution should be exercised in applying these data as growth restricted preterm infants were excluded from one of the included studies, ${ }^{12}$ and this subpopulation may be at increased risk of developing NEC. ${ }^{21}$
Given the uncertainty about the clinical applicability of these findings, should further studies be undertaken? NEC remains a major cause of death and debility in preterm infants, and improved strategies for prevention are required. However, there are concerns about the nutritional adequacy of donor breast milk. Future studies would be able to compare growth, development, and adverse events in infants fed with nutrient fortified donor human milk versus formula milk. Implementing this intervention would require the reestablishment of donor milk banks that were closed in the $1980 \mathrm{~s}^{22}$ despite the lack of data to suggest a significant risk of transmission of HIV and other infectious agents via donor milk. ${ }^{23}$ The costs and feasibility of using donor human milk should be compared with those of other interventions that might reduce the incidence of NEC, such as the supplementation of formula milk with immunoglobulin. ${ }^{25}$ These trials should be undertaken in infants who are at very high risk of developing NEC, such as very low birthweight infants. Carers and assessors should be blind to the intervention because the threshold for investigation or diagnosis may be affected by knowledge of the type of milk received. About 900 infants would be required to participate in a large (about 30 centres with an established donor milk bank) pragmatic trial in order to detect the estimated size of effect found in this review (with $95 \%$ confidence and at $80 \%$ power).

\section{Authors' affiliations}

W McGuire, Tayside Institute of Child Health, Ninewells Hospital and Medical School, Dundee DDI 9SY, Scotland, UK

M Y Anthony, Special Care Baby Unit, Department of Paediatrics, John Radcliffe Hospital, Oxford OX3 9DU, UK

\section{REFERENCES}

1 American Academy of Pediatrics and Workgroup on Breastfeeding. Breastfeeding and the use of human milk. Pediatrics 2000; 100: 1035-9.

2 Beeby PJ, Jeffery H. Risk factors for necrotising enterocolitis: the influence of gestational age. Arch Dis Child 1992;67:432-5.

3 Lucas A, Cole TJ. Breast milk and neonatal necrotising enterocolitis. Lancet 1990; 336:1519-23.

4 Schanler RJ, Shulman RJ, Lau C. Feeding strategies for premature infants: beneficial outcomes of feeding fortified human milk versus preterm formula. Pediatrics 1999;103:1150-7.

5 McGuire W, Anthony MY. Formula milk versus preterm human milk in preterm or LBW infants (Cochrane Review). The Cochrane Library. Oxford: Update Software, 2001 : issue 3.

6 Gross SJ, Buckley RH, Wakil SS, et al. Elevated IgA concentration in milk produced by mothers delivered of preterm infants. J Pediatr 1981;99:389-93.

7 Gross SJ, Geller J, Tomarelli RM. Composition of breast milk from mothers of preterm infants. Pediatrics $1981 ; 68: 490-3$.

8 Suzuki S, Lucas A, Lucas PJ, et al. Immunoglobulin concentrations and bacterial antibody titres in breast milk from mothers of 'preterm' and 'term' infants. Acta Paediatr Scand 1983;72:671-7.

9 Lucas A, Gore SM, Cole TJ, et al. Multicentre trial on feeding low birth weight infants: effects of diet on early growth. Arch Dis Child 1984;59:722-30.

10 Svenningsen NW, Lindroth $M$, Lindquist $B$. A comparative study of varying protein intake in low birth weight infant feeding. Acta Paediatr Scand Suppl 1982;296:28-31.

11 Tyson JE, Lasky RE, Mize CE, et al. Growth, metabolic response, and development in very-low-birth-weight infants fed banked human milk or enriched formula. I. Neonatal findings. J Pediatr 1983;103:95-104.

12 Gross SJ. Growth and biochemical response of preterm infants fed human milk or modified infant formula. N Engl J Med 1983;308:237_ 41.

13 Raiha NC, Heinonen K, Rassin DK, et al. Milk protein quantity and quality in low-birth weight infants. I. Metabolic responses and effects on growth. Pediatrics 1976:57:659-84.

14 Davies DP. Adequacy of expressed breast milk for early growth of preterm infants. Arch Dis Child 1977;52:296-301.

15 Schultz K, Soltesz G, Mestyan J. The metabolic consequences of human milk and formula feeding in premature infants. Acta Paediatr Scand 1980;69:647-52.

16 Narayanan I, Prakash K, Gujral VV. The value of human milk in the prevention of infection in the high-risk low birth weight infant. J Pediatr $1981 ; 99: 496-8$.

17 Narayanan I, Prakash K, Prabhakar AK, et al. A planned prospective evaluation of the anti-infective property of varying quantities of expressed human milk. Acta Paediatr Scand 1982;71:441-5. 
18 Putet G, Senterre J, Rigo J, et al. Nutrient balance, energy utilization, and composition of weight gain in very low birth weight infants fed pooled human milk or a preterm formula. J Pediatr 1984; 105:79-85.

19 Carey DE, Rowe JC, Goetz CA, et al. Growth and phosphorus metabolism in premature infants fed human milk, fortified human milk, or special premature formula. Use of serum procollagen as a marker of growth. Am J Dis Child 1987;141:511-15.

20 Armand $M$, Hamosh M, Mehta NR, et al. Effect of human milk or formula on gastric function and fat digestion in the premature infant. Pediatr Res 1996;40:429-37.
21 McDonnell M, Serra-Serra V, Gaffney G, et al. Neonatal outcome after pregnancy complicated by abnormal velocity waveforms in the umbilical pregnancy complicated by abnormal velocity waveforms in the

22 McClure RJ, Chatrath MK, Newell SJ. Changing trends in feeding policies for ventilated preterm infants. Acta Paediatr 1996;85: 1 123-5. 23 Lucas A. AIDS and human milk bank closures. Lancet 1987;1:1092-3. 24 Eglin RP, Wilkinson AR. HIV infection and pasteurisation of breast milk. Lancet 19́87; 1:1093.

25 Foster J, Cole M. Oral immunoglobulin for preventing necrotizing enterocolitis in preterm and low birth weight neonates (Cochrane review). The Cochrane Library. Oxford: Update Software, 2001 : issue 3.

\section{ADC web submission and review system}

The Editors of $A D C$ are pleased to inform authors and reviewers of its new online submission and review system. Developed by Highwire Press (CA, USA), Bench>Press is a fully integrated electronic system which uses the internet to allow rapid and efficient submission of manuscripts, and for the peer review process to be conducted entirely online. We are the first journal of the BM publishing group to go online in this way; the aim, apart from saving trees, is to speed up the frequently frustrating progress from submission to publication.

Authors can submit their manuscript in any standard word processing software. Standard graphic formats acceptaed include: .jpg, .tiff, .gif, eps, etc. The text and graphic files are automatically converted to PDF for ease of distribution and reviewing purposes. Authors are asked to approve their submission before it formally enters the reviewing process. On approval, the submission is passed to the editor and/or reviewers via the web. All transactions are secure.

To access the system click on "SUBMIT YOUR MANUSCRIPT HERE" on the ADC homepage: http://www.archdischild.com, or you can access the submission site directly at http://submitadc.bmijournals.com.

We are very excited with this new development and would encourage authors and reviewers to use the system where possible. It is simple to use and should greatly improve on the current peer review process. Full instructions can be found on Bench>Press and $A D C$ online. 